\title{
Research on Curriculum System of Vocational Teachers Cultivation about Animation Professional
}

\author{
Wei Dandan ${ }^{1, a^{*}}$, Qiu Lexing ${ }^{2, b}$ \\ ${ }^{1}$ Education College Jiangxi Science and Technology Normal University, China \\ ${ }^{2}$ Educational Technology Center Nan Chang Army College, China \\ aqlxwdd@163.com, ${ }^{b}$ qlx98@tom.com
}

Keywords: Vocational education, Animation professional, Teachers cultivation.

Abstract. This thesis is on the basis of domestic and foreign animation related professional teachers' training literature research program, the domestic animation related professional teachers' training practice of on-the-spot investigation, and analyze animation related professional teachers typical tasks and occupation ability, then develop the course system structure.

\section{Introduction}

Animation majors in vocational colleges and some universities is not a long time, or even still in the exploratory stage, therefore, in professional teaching, there are many problems, such as confusion, professional teaching curriculum is not reasonable teaching goals are not clear, and so on. Because some animation software for professional operations more intricate, which will operate the software teachers rarely, so students can learn the most fundamental and most simple functions, and less likely to contact advanced software latter operation.

There are even some schools simply did not have the classes about the software programs. Imagine this kind of hardware facilities, the level of education is bound to affect higher education of animation, as well as profession animation training of vocational teachers. Therefore, we need to develop reasonable course system that a set of high quality, model animation professionals on developing vocational teachers, so that its relevance and effectiveness in order to train high-quality animation in secondary vocational school teachers to promote animation professional teacher development and promote our country's system being perfected where animation professional occupation teacher's education.

\section{Organization Of The Text Development Idea}

Emphasizes the integrity of the system, fully embodies the "vocational, technical and teacher-training" combining. With the economic and social development rapidly, new technologies emerge constantly, equipment and products, constantly updated .Community's expertise in Proficient in the production and service of professional skills increasingly demanding, request academic standards, but also have a certain level of skills.

Implementing vocational action ability-oriented education teaching ideas, emphasizes integration of theory and practice training to strengthen teaching professional theory and practice, the integration of theory and practice. Action-oriented teaching has become the primary mode of teaching in vocational education, which thinks an action or task-oriented as a guiding of vocational education teaching guiding ideology, consists of a series of student-centered teaching methods and pedagogy of composition.

Project learning into action-oriented teaching the main form of learning. typical characteristics of action-oriented teaching is situational, it is emphasized close to the real work environment is emphasized, such as learning islands, learning in the work process, learning on the job. Implementation of this educational idea, animation professional vocational teacher training standards should emphasize the integration of theory and practice of training to strengthen teaching of professional theory and practice, the integration of theory and practice. 
Enhance cooperation with vocational schools, relevant industries and enterprises, realize the diversity of working and learning alternation training. Animation professional secondary vocational school teachers' standard (draft) put forward "animation professional secondary vocational school teachers should have good professional ethics, master animation professional knowledge and professional skill, master animation production process and work standard, has the high art aesthetic quality, and has strong ability of vocational teaching corresponding professional animation, to serve as secondary vocational schools (including computer animation and game production, animation game profession, digital image technology, image and video technology, digital media, digital media art, etc in animation related major of teaching) and scientific research". This needs to be animated in the process of strengthening professional vocational education teacher training practice, in-depth cooperation with corresponding vocational schools and industry enterprise, to develop animation profession teachers in the standard requirement.

Considering the sustainable development of the student requirement, pay attention to the broad professional foundation and outstanding professional focus direction. To become a qualified teacher of secondary vocational school, need to lifelong learning, learning animation professional knowledge, professional education theory and professional skills, learning and absorbing the domestic and foreign advanced vocational education idea and experience. Participate in professional practice, figure the animation industry, animation business demand and the change of professional post, constantly follow up technological progress. Optimizing knowledge structure and ability structure, improving cultural quality and professional quality. Have the consciousness and ability of lifelong learning and sustainable development, make the model of lifelong learning. Love vocational education business, performance of the teachers' professional ethics, with professional idea of compatible with animation professional, cultural knowledge, professional knowledge, professional skills and vocational education and teaching knowledge and ability. Need to pay attention to while animation professionals on developing vocational teachers' sustainable development requirements, focusing on Broader scope of knowledge Clear professional focus.

Focus on courses teaching contents and teacher certification requirements, the consist professional courses with qualifications consistency. Professional qualification certificate and professional labor activities closely linked, reflecting the specific profession practical work standards and specifications. Professional qualification certificate is an important content of labor employment system, also is a kind of special form of national examination system, refers to the vocational skills according to the national standards or qualifications, through the inspection appraisal agencies acknowledged by the government, the skill levels of workers or professional qualification for objective and fair, scientific and standardized evaluation and appraisal, to pass with the corresponding national professional qualification certificate. Animation professional teachers for normal requirement pay attention to the cultivation of the teachers' qualification, while professional, technical demands, pay attention to the cultivation of the professional qualification when training course to notice in conformance with the corresponding qualification certificate.

According to the teaching rule and the principle of gradual and clarify the logical relationship between different course module, forming an organic curriculum system. Comply with laws of vocational talents growth and education teaching, if clarify the logical relationship between the training scheme in the course, to form the scientific and reasonable that the order of the courses, so as to improve the efficiency of teaching, form obeys the law of professional education scientific and reasonable curriculum system. Animation professional vocational education teacher training should be around the target of profession fostering thinking about the composition of the professional courses, clarify the logical relationship between different course module, forming an organic curriculum system.

\section{Main Subject And Curriculum Structure}

When research team in determine the course structure and professional main courses, emphasizing enterprise personnel, secondary vocational school teachers to participate in, to jointly develop course. Curriculum development should be based on the following principles: First, with 
quality education and innovation education as the theme, aim to cultivate innovative talents. In the curriculum, on the one hand the courses in about innovation education, make students understand and grasp the basic theory and method of innovation and entrepreneurship .On the other hand, We need encourage students to participate in various competitions, participate in applied science and technology development, cultivate students' spirit of innovation, promote the formation of students' innovation consciousness, to strengthen the students' innovation ability, improve the students' professional spirit and the ability to adapt society. Second, combining theory with practice, highlight the skills. Implement modular teaching in teaching, project teaching, raising the integration of teaching. As animation professional vocational education teacher training, In order to realize the teachers with "workshop", the theory and practice, combining software with hardware, combined with the students, teachers and technicians, combined with an apprentice, works and products, as well as the combination of education and income generation, let the students learn in practice, practice in learning. Third, the curriculum combined with professional qualification. Occupational qualification certification examinations in animation teaching, in standard and content are integrated into the course, the organic combination of teaching and professional qualification appraisal.

The Main Subject. Main subject is determined by the training objectives and to obtain the ability structure must have the professional theory and skills system. Curriculum group on the basis of undergraduate animation professional talent training scheme research results, and refer to the ministry of education of the specialty catalogue and introduction of undergraduate course of common colleges and universities(2012) animation professional main subjects television, drama, arts, design, art theory, because the subject system include art design, fine arts, drama, film, etc., combining with the characteristics of vocational education teacher training, the team will be setting the main subjects of art, vocational pedagogy.

The Structure of the Courses. Around the above set of training objectives, Study of the vocational education students of normal colleges should complete the following two aspects: the core ability of learning: (1) the professional theory and practice; (2) Vocational education teaching theory and practice. According to the knowledge structure of curriculum, strengthening basic theory, highlight the core curriculum, coverage and reflect the certain knowledge of vocational education teachers' lifelong learning and sustainable development of the service; According to the ability structure of the curriculum, reflects the characteristics of vocational education teacher training, to strengthen the teaching of professional courses, which pay attention to cultivate the students' professional ability, technical skills, the education teaching ability, innovation, entrepreneurship, etc.

Team research main subject as the main line, set up the ability oriented animation professional vocational education teacher training curriculum structure, that is "wide foundation, active module, more direction". Taking ability as the training curriculum guide set animation professional vocational teachers, Concrete analysis is as follows: Credit assignment training of vocational teachers in German, The formulation of constructive teaching system of teaching plan and design practical reference value. The vast majority of our teachers college teaching plan, major, minor professional, education of science, the percentage of three part of the class about is 2:1:1. And the class distribution training of vocational teachers in German close. Therefore, the research group to set up such as the curriculum structure shown in Table 1.

Table1 Hours distribution of animation professional teachers of vocational education curriculum structure and the credits

\begin{tabular}{|c|c|c|c|}
\hline Course type & The nature of the course & Credit & Hours \\
\hline \multirow{2}{*}{ General education curriculum ( $28 \%$ ) } & Compulsory & 38 & 789 \\
\hline & Elective & 8 & 120 \\
\hline Basic courses in discipline $(17 \%)$ & Compulsory & 28 & 492 \\
\hline Courses in Specialty $(21 \%)$ & Compulsory & 34 & 704 \\
\hline Occupation of Teacher Education Curriculum ( $14 \%$ ) & Compulsory & 22 & 190 \\
\hline Occupation orientation course ( $7 \%$ ) & Three elective direction & 12 & 288 \\
\hline Centralized practice course ( $13 \%)$ & Compulsory & 22 & 25 Weeks \\
\hline \multicolumn{2}{|l|}{ Subtotal } & 164 & 2583 \\
\hline
\end{tabular}




\section{Main Professional Courses And Curriculum System}

The Main Courses. The main courses of professional training objectives and achieve the main course is the knowledge and ability structure must be opened for the realization. Research on Enterprises Research, Clear the occupation post and professional task facing, And occupation related positions have the ability, As shown in Table 3.

Ability task group needed for a link to the actual work process of series, Set the main course corresponding professional, as shown in table 2.

Table2 Analysis of professional occupation post and animation

\begin{tabular}{|l|l|l|}
\hline Category & Post & The work of the task \\
\hline 1 & $\begin{array}{l}\text { Animators ; A character animator } \\
\text { A scene designer ; The designer }\end{array}$ & $\begin{array}{l}\text { The role of design ; Storyboard design ; Scene design ; Props } \\
\text { design }\end{array}$ \\
\hline 2 & $\begin{array}{l}\text { Role model division;Scene } \\
\text { lighting division;Scene } \\
\text { modeling Division;Animation and special } \\
\text { effects artist }\end{array}$ & $\begin{array}{l}\text { Three dimensional model making ; A light material production; } \\
\text { Three dimensional animation ; Game animation ; The special } \\
\text { effects production }\end{array}$ \\
\hline 3 & Cartoonists ; CG illustrator & Drawing cartoons ; Illustration \\
\hline 4 & Game Art & Game concept design; game scene design; game role design \\
\hline 5 & $\begin{array}{l}\text { The film post production division ; } \\
\text { Animation post processing division }\end{array}$ & $\begin{array}{l}\text { Video clips synthesis; special effects } \\
\text { production synthesis; application of the virtual reality software }\end{array}$ \\
\hline
\end{tabular}

According to the analysis of professional posts and the ability of the above animation, art, vocational education as the main subjects, and vocational teachers should master the vocational education teaching knowledge and ability, professional animation teacher must learn the professional main courses in addition to animation sketch, color, sketch.

The Curriculum System. The curriculum system development principle: (1) According to the enterprise technical route design curriculum system, renewing teaching contents according to the technology development trend. (2) The active use of teaching methods and means of occupation education. (3) Focus on skills training, Strengthening Practice Teaching

\section{Summary}

Animation based on the vocational professional teaching standards ( Draft ), Animation major secondary vocational school teachers should have good professional ethics, Animation master professional knowledge and professional skills, familiar with the animation production process and job specifications, And have a strong professional teaching skills, able to serve as the secondary vocational school specializing in animation(including animation and game production professionals, Animation and game Professional, digital imaging, video and television technology, Digital Media Technology, digital media arts and animation related ) teaching and research. Animation of the program aims at training professional teaching staff of Vocational Education employment areas covered by the corresponding profession, Includes computer animation and game design, animation and game professional,Digital imaging, video and television technology', Digital Media Technology, digital media arts and animation related. Therefore, the Task Force on professional abilities developed three corresponding vocational orientation That is, animation and game design and production, Film and Television animation direction, Digital Media creation direction.

\section{References}

[1]Quan Ren. The animation of Australian university talents training characteristics and Enlightenment of higher correspondence.2009.3.

[2]Zhang Yan. China Education Innovation Herald. animation talents training.2010.4.

[3]Du Cuiyun. Undergraduate animation education reform. Shaanxi Normal University.2012.5. 
International Conference on Engineering Management, Engineering Education and Information Technology (EMEEIT 2015) 